\title{
Tongue Squamous Cell Carcinoma
}

National Cancer Institute

\section{Source}

National Cancer Institute. Tongue Squamous Cell Carcinoma. NCI Thesaurus. Code C4648.

A squamous cell carcinoma that arises from the tongue. It usually presents as a painful ulcerated or nodular lesion. The size of the tumor and the status of the lymph nodes are the most important factors that determine prognosis. 